\title{
Birds foraging for fruits and insects in shrubby restinga vegetation, southeastern Brazil
}

\author{
Verônica Souza da Mota Gomes ${ }^{1,3,4}$, Bette A. Loiselle ${ }^{2}$ \& Maria Alice S. Alves ${ }^{3}$ \\ ${ }^{1}$ Programa de Pós-Graduação em Ecologia, Universidade Federal do Rio de Janeiro - UFRJ, \\ Ilha do Fundão, CCS, Bloco A, Sala A1 008, \\ CP 68020, CEP 21941-590, Rio de Janeiro, RJ, Brazil, www.ufrj.br \\ ${ }^{2}$ Department of Biology, 8001, Natural Bridge Road, University of Missouri, \\ St. Louis, St. Louis, MO 63121-4499, USA, www.umsl.edu \\ ${ }^{3}$ Departamento de Ecologia, IBRAG, Universidade do Estado do Rio de Janeiro - UERJ, \\ Rua São Francisco Xavier, 524, Maracanã, CEP 20550-011, Rio de Janeiro, RJ, Brazil, \\ e-mail:masaal@globo.com,www.uerj.br \\ ${ }^{4}$ Corresponding author: Verônica Souza da Mota Gomes, e-mail: vsmgomes@yahoo.com.br
}

GOMES, V.S.M., LOISELLE, B.A. \& ALVES, M.A.S. 2008. Birds foraging for fruits and insects in shrubby restinga vegetation, southeastern Brazil. Biota Neotrop. 8(4): http://www.biotaneotropica.org.br/v8n4/en/ abstract?article+bn00208042008.

\begin{abstract}
Understanding how birds use vegetation to obtain food resources has implications for habitat conservation and management. Restinga is a poorly known and threatened tropical habitat, associated to the Atlantic forest, that could benefit from this kind of information to know which plants can be used and dispersed by birds that can help on the maintenance of this habitat. Frugivorous and insectivorous birds are important components of tropical ecosystems, such as restinga. To provide more information regarding the ecology of restinga, we studied the feeding behavior and spatial use of this vegetation by birds at Restinga de Jurubatiba National Park, southeastern Brazil. We found that feeding behavior was similar to that recorded for the same species in other vegetation types. In addition, spatial use of the restinga vegetation by the most abundant species did not overlap greatly, except for two insectivorous species that used different foraging maneuvers and two frugivorous birds that foraged in flocks. The two most abundant species were generalists in their diet and were capable of feeding at the ground level on sand substrate.
\end{abstract}

Keywords: Atlantic forest, behavior, diet, Mimus gilvus, Zonotrichia capensis.

GOMES, V.S.M., LOISELLE, B.A. \& ALVES, M.A.S. 2008. Forrageamento de aves por frutos e insetos em restinga arbustiva, sudeste do Brasil. Biota Neotrop., 8(4): http://www.biotaneotropica.org.br/v8n4/pt/ abstract?article+bn00208042008.

Resumo: O conhecimento das estratégias de uso da vegetação pela fauna para forrageio tem implicações para conservação e manejo de habitats. Restinga é um ambiente tropical, associado à Mata Atlântica, ameaçado e ainda pouco conhecido que poderia se beneficiar desse tipo de informação para conhecer quais espécies de plantas podem ser utilizadas e dispersas por aves que atuem na manutenção deste habitat. Aves frugívoras e insetívoras são importantes componentes de ecossistemas tropicais, como a restinga. Para fornecer mais informações sobre a ecologia da restinga, nós estudamos o comportamento de forrageio e o uso do espaço das aves no Parque Nacional da Restinga de Jurubatiba, sudeste do Brasil. Nós encontramos que os comportamentos de forrageio foram similares àqueles registrados para as mesmas espécies em outros ambientes. Além disso, o uso do espaço da vegetação de restinga pelas espécies mais abundantes não apresentou grande sobreposição, exceto por duas espécies insetívoras que usaram manobras de forrageio diferentes e duas aves frugívoras que forragearam em bando. As duas espécies mais abundantes foram generalistas em suas dietas e foram capazes de forragear no chão sobre areia nua.

Palavras-chave: Mata Atlântica, comportamento, dieta, Mimus gilvus, Zonotrichia capensis. 


\section{Introduction}

Foraging ecology of birds often is limited by foliage structure, plant height and life forms and, therefore, plant community composition influences the ecology and composition of bird communities (Robinson \& Holmes 1982, 1984, Holmes \& Recher 1986, Parker 1986, Whelan 2001, Hasui et al. 2007). Furthermore, some birds forage preferentially on certain plant species (e.g., Parker 1986, Warburton et al. 1992), such as conifer trees of economic importance (Airola \& Barrett 1985). Birds also are known to forage at different heights in the same plant species as shown by the classic work of MacArthur (1958) and others (Holmes et al. 1979, Parker 1986). This pattern corroborates the idea that closely-related species that co-occur rarely use the same habitat in the same way, avoiding competition for limited resources (Wiens 1989). Past and present selection, therefore, influences the ecology of interactions within any vegetation type, as well as the strength of those interactions. Some changes in vegetation structure and composition caused by deforestation may disrupt those interactions and change bird community composition (Canterbury et al. 2000, Gabbe et al. 2002, Sekercioglu 2002). Therefore, understanding how birds specifically use vegetation and individual plant species to obtain food resources likely has implications for habitat conservation and management, pointing out important plant species or structures that could be chosen for habitat restoration, which could attract seed dispersers to the area (Meli 2003), resulting in acceleration of forest succession (McClanahan \& Wolfe 1993).

Frugivorous birds are important components of ecosystems, as they influence plant regeneration through seed dispersal (Stiles 1992, Gorchov et al. 1993, Pizo 1997, Howe \& Miriti 2000, Bleher $\&$ Bohning-Gaese 2001). However, foraging behavior of birds may influence their effectiveness as dispersers (Sorensen 1984, Schupp 1993, Witmer \& Van Soest 1998). Similarly, insectivorous birds are important components of ecosystems as they may control populations of insect herbivores on certain plant species (Van Ball et al. 2003); their preferences for some foraging microhabitats generally determine what species or type of prey are eaten (Wolda 1990).

Restinga is a coastal Brazilian ecosystem that is geologically recent and relatively poor in the number of endemic species; flora and fauna of restinga are typical of the Atlantic forest (Rizzini 1979, Lacerda et al. 1993, Cerqueira 2000, Reis \& Gonzaga 2000, Alves et al. 2004). However, there is little ecological information on restinga birds to confirm whether they have similar habits to other tropical ecosystems, including other vegetation types within the Atlantic forest region (but see Novaes 1950, Venturini et al. 1996, Castiglioni 1998, Argel-de-Oliveira 1999, Scherer et al. 2007). The seasonal presence of non-breeding birds (Gonzaga et al. 2000, Alves et al. 2004) and the great threat to restinga from farmers and construction of second homes along the beach (Lacerda et al. 1993) highlight the importance of ecological studies that may inform conservation measures. Furthermore, marginal habitats to the Atlantic forest as restingas are often neglected in conservation strategies (Scarano 2002).

The main goal of the present study is to examine spatial use of restinga vegetation by the most common terrestrial birds when foraging on fruits and/or arthropods. In addition, we present information on general foraging ecology of 37 other bird species that also feed on fruits and arthropods in restinga. By indicating what plants birds prefer to forage on and how they partition space during foraging, we expect to contribute to support conservation of restinga vegetation.

\section{Material and Methods}

Data were collected in the Restinga de Jurubatiba National Park ( $22^{\circ} 17^{\prime} \mathrm{S}$ and $\left.41^{\circ} 41^{\prime} \mathrm{W}\right)$, created in 1998 in Macaé, on the north shore of Rio de Janeiro State. This region is a holocenic sandy plain covered by a mosaic of plant communities called restinga. The landscape is also marked by the presence of many coastal lakes with various salinity levels. Climate is characterized by a wet season between October and April and a drier season between May and September. Mean annual rainfall is $1200 \mathrm{~mm}$ and temperature $22.6^{\circ} \mathrm{C}$. The dominant plant formation is the Open Clusia Formation, formed by patches of vegetation that cover 20 to $48 \%$ of the soil and reach $5 \mathrm{~m}$ high, with few small plants in between. The Park also includes forest formations, Ericaceae Shrub Formation and other formations with smaller plants, totaling ten plant communities (Henriques et al. 1986, Araujo et al. 1998, Pimentel 2002). The present study was developed in the Open Clusia Formation in two sites: next to "Lagoa Comprida" (22 $2^{\circ} 16^{\prime} 41^{\prime \prime} \mathrm{S}$ and $\left.41^{\circ} 39^{\prime} 41^{\prime \prime} \mathrm{W}\right)$ and approximately two kilometers to northeast from that site $\left(22^{\circ} 16^{\prime} 13.2^{\prime \prime} \mathrm{S}\right.$ and $\left.41^{\circ} 38^{\prime} 50.3^{\prime \prime} \mathrm{W}\right)$.

Observations were made between 6:00 and 12:00 $\mathrm{h}$ and between 13:00 and 18:00 h, walking along three parallel transects in each site. Each trail was approximately $200 \mathrm{~m}$ long and $50 \mathrm{~m}$ distant from any other transect. We walked at a constant speed until a foraging bird was detected; the bird was followed until lost. During $100 \mathrm{~h}$ of observations, we recorded the following information: bird species (following Dunning 1989, Sick 1997, and museum collections for Elaenia spp.), plant species (when possible), foraging height, foraging position (relative to plant height), food item and foraging behavior (maneuver). Foraging maneuvers were characterized as one of nine types (adapted from Remsen \& Robinson 1990), and then grouped into five categories: glean, on-perch maneuvers (reach, hang), sally (sally-strike, sally-pounce, sally-hover), ground maneuver (leap, lunge), and hawk. Food items considered were fruits and arthropods, and to determine predominance of one or the other in each species' diet, we considered the occurrence of those items in fecal samples and observations. Fecal samples were obtained from all birds captured, except for Columbina spp. (essentially seed-eaters), Trochilidae (essentially nectar-feeders) and nocturnal birds during 3640 net-hours ( $2.5 \times 12 \mathrm{~m} ; 36 \mathrm{~mm}$ mesh). Common names are as in Dunning (1989) and authors and years from CBRO (2007).

We determined the relative availability of plant species to evaluate the foraging sites available and used by birds. Shrubs and trees (with $2.5 \mathrm{~cm} \mathrm{DBH}$ or greater) with $0.5 \mathrm{~m}$ or taller were sampled using the point-centered quarter method (Sylvestre \& Rosa 2002). In each sample area, two transects separated by $40 \mathrm{~m}$, with 25 points spaced at $10 \mathrm{~m}$ intervals were sampled; this resulted in a total of 400 plants sampled. At each sample point, we identified and measured the distance and circumference at $0.5 \mathrm{~m}$ height for the four plants closest to each point. We then calculated the Importance Value Index (IVI, Brower \& Zar 1984) for each species, taking into account relative frequency (in 100 points), relative abundance and relative cover (basal area at $0.5 \mathrm{~m}$ high). Availability of each plant species was calculated as the total IVI for that species. From the available plants, $35 \%$ were identified only to morphospecies. We estimated the preference of bird species for each plant species using Jacobs' index:

$$
\mathrm{D}=(\mathrm{u}-\mathrm{p}) /(\mathrm{u}+\mathrm{p}-2 \mathrm{up})
$$

where:

$\mathrm{u}$ is proportion of that plant species used by the bird species, and $\mathrm{p}$ is proportion of plant species available (Jacobs 1974). Only the plant species used when foraging for arthropods were used in this analysis, as fruit consumption depends on variables other than plant availability (e.g., fruit size, fruit abundance, chemistry) and will be discussed elsewhere. From the species used by the birds, only five species were not identified.

Here we include in each statistical analysis only the bird species with at least five independent observations for each variable (height, 
position, maneuver and plant species used to obtain arthropods or fruits), which we find to be the minimum to establish a pattern. This criterium resulted in five bird species studied in detail. To assure independent observations, only the first observation of sequential observations from an individual was used (Bell et al. 1990, Hejl et al. 1990). The main objective with these analyses was to draw a picture of the main foraging birds in restinga and indicate important plant species or structures. The classic discussion concerning competition between similar species is only approximated when comparing Coryphospingus pileatus (Wied) and Zonotrichia capensis (Müller) or Campstostoma obsoletum (Temminck) and Elaenia flavogaster (Thunberg), the most similar species with the minimum sample sizes.

To observe differences in the foraging heights, we built up notched Box Plots (Systat, 1990). To group bird species according to their maneuvers, plant species, and position on the plant, we used BrayCurtis Ordination (BCO) (McCune \& Mefford 1999), as it avoids grouping species together based on the presence of zeros in the data matrix (Beals 1984). Parameters used for these analyses followed McCune \& Grace (2002).

\section{Results}

We recorded 1.53 individuals foraging per hour of observation. This low encounter rate reflects the difficulty in detecting foraging birds in this habitat. Although it is an open habitat, the vegetation patches often are dense and compact. From the bird species detected foraging, $71.4 \%$ were frugivorous (fruits consumed in at least one observation), while the remaining species consumed animals (mainly arthropods - insectivorous) (Table 1).

We recorded foraging observations from 162 individuals of 25 species. The most common foraging maneuver observed was gleaning from a perch (20 species), while sally maneuvers were used by 10 species (Table 1). Only two species foraged from the ground and five species used hawking maneuvers. When the five most commonly observed species were grouped by their feeding maneuvers, the first axis extracted $81.09 \%$ of the variation and the second $18.42 \%$. Mimus gilvus (Vieillot) and Zonotrichia capensis clustered together in the ordination because they occasionally fed from the ground, although they used a variety of foraging maneuvers (Figure 1). In contrast, Elaenia flavogaster, which frequently sallied, separated from the others; while Camptostoma obsoletum and Coryphospingus pileatus grouped together due to a preference for gleaning.

When species were ordinated based on plant species used for foraging on arthropods, the first axis extracted $80.0 \%$ of the variation and the second axis extracted another 16.7\%. Camptostoma obsoletum and E. flavogaster presented the greatest similarity in plant species used as foraging sites (Figure $2 \mathrm{a}$ and b). However, the ordination of birds in plant species space based on foraging for fruits (first axis with $89.25 \%$ and second with $10.72 \%$ ) revealed that $Z$. capensis and $C$. pileatus were the species most similar to each other (Figure 2c and d).

Concerning foraging heights, E. flavogaster clearly preferred the highest heights, significantly differing from C. pileatus, M. gilvus and Z. capensis (no confidence interval overlap) (Figure 3). On the other extreme, Z. capensis preferred the lowest heights and differed also from C. pileatus and M. gilvus. Camptostoma obsoletum did not show a clear preference, not differing from the other four species.

Finally, the first axis of BCO for position extracted $87.7 \%$ and the second $11.6 \%$. Zonotrichia capensis and E. flavogaster formed a group that preferred the upper part of the plants (from 50 to $99 \%$ of plant total height), while $M$. gilvus and C. pileatus used the top of plants and C. obsoletum did not show any preference (Figure 4).
Based on the results presented here, it was possible to establish the spatial arrangement of the five species while foraging (Figure 5). Mimus gilvus occasionally foraged on the ground, although it preferred to forage on the top of plants, both in tall and short plants. It used many different plant species during its foraging activity for arthropods and for fruits. Elaenia flavogaster used the upper part of the plants and foraged at the greatest heights, both when foraging for arthropods and for fruits. Ocotea notata was a plant frequently used by that species. Camptostoma obsoletum was not observed foraging for fruits and used all heights and vertical positions equally. Some plants used by this species as foraging sites were also used by E. flavogaster (Figure 5a). Coryphospingus pileatus did not show any preference for height, but preferred to forage in the canopy of plants. Zonotrichia capensis foraged at lower heights, but preferred the crown position. The latter two species presented some overlap while foraging for fruits in lower-level vegetation, but not for arthropods (Figure $5 \mathrm{a}$ and $\mathrm{b}$ ).

Four of the five bird species studied preferred to forage on Ocotea notata (Nees) Mez disproportionate to its availability (Table 2). The preference of C. obsoletum for Garcinia brasiliensis Mart. was probably numerical, rather than biological, and related to the low abundance of this plant species. Mimus gilvus' preference for Clusia hilariana Schltdl. seems biological, as this plant was the second most available and was used considerably more than expected.

\section{Discussion}

Despite that restinga is an open habitat, with highly patchy vegetation and a harsh climate, bird species studied in detail were similar in their foraging ecologies to the same or closely-related species in tropical humid forests. The five most common species differed in height and plant species preferences, with little spatial overlap. Probably those characteristics are linked to their evolutionary histories in

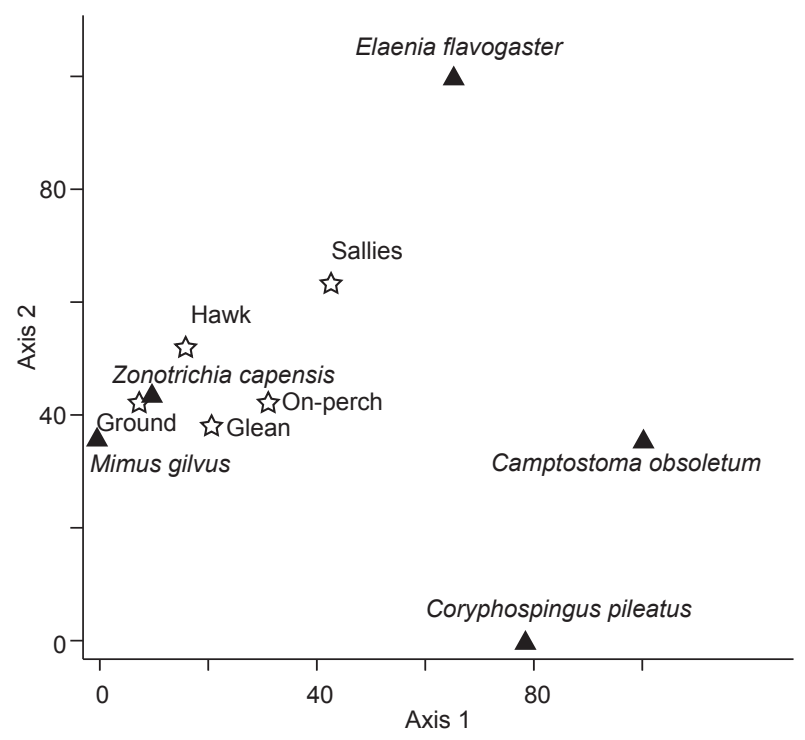

Figure 1. Bray-Curtis Ordination (BCO) of the studied species considering maneuvering, at Restinga de Jurubatiba, Rio de Janeiro State, Brazil. (Scores for the birds are triangles and for the variables are stars; for number of samples, see Table 1).

Figura 1. Ordenação de Bray-Curtis (BCO) das espécies estudadas considerando comportamento, na Restinga de Jurubatiba, Estado do Rio de Janeiro, Brasil. (Posições das aves são triângulos e das variáveis são estrelas; para número de amostras, veja Tabela 1). 
Table 1. Feeding data on the terrestrial birds observed foraging in Restinga de Jurubatiba, Rio de Janeiro State, southeastern Brazil.

Tabela 1. Informações de alimentação das espécies de aves terrestres observadas forrageando na Restinga de Jurubatiba, Estado do Rio de Janeiro, sudeste do Brasil.

Family
Species

\section{Fecal or regurgitate samples \\ Observations}

$\begin{array}{cccccc}\mathbf{N} & \begin{array}{c}\text { Art } \\ (\%)\end{array} & \text { Fruits } & \mathbf{N} & \begin{array}{c}\text { Art } \\ (\%)\end{array} & \begin{array}{c}\text { Fruits } \\ (\%)\end{array} \\ & & & (\%)\end{array}$

\section{COLUMBIDAE CUCULIDAE}

EMBERIZIDAE

MIMIDAE
MUSCICAPIDAE
PICIDAE
THAMNOPHILIDAE
TROGLODYTIDAE
TYRANNIDAE

TYRANNIDAE

\section{Leptotila rufaxilla (Richard \& Bernard, 1792) \\ Coccyzus americanus (Linnaeus, 1758) \\ Coccyzus melacoryphus Vieillot, 1817 \\ Cacicus haemorrhous (Linnaeus, 1766) \\ Coereba flaveola (Linnaeus, 1758) \\ Coryphospingus pileatus (Wied, 1821) \\ Cyanerpes cyaneus (Linnaeus, 1766) \\ Euphonia chlorotica (Linnaeus, 1766) \\ Nemosia pileata (Boddaert, 1783)}

Ramphocelus bresilius (Linnaeus, 1766)

Schistochlamys ruficapillus (Vieillot, 1817)

Tachyphonus coronatus (Vieillot, 1822)

Tangara peruviana (Desmarest, 1806)

Thraupis sayaca (Linnaeus, 1766)

Volatinia jacarina (Linnaeus, 1766)

Zonotrichia capensis (Statius Muller, 1776)

Mimus gilvus (Vieillot, 1807)

Mimus saturninus (Lichtenstein, 1823)

Platycichla flavipes (Vieillot, 1818)

Turdus albicollis Vieillot, 1818

Turdus amaurochalinus Cabanis, 1850

Celeus flavescens (Gmelin, 1788)

Picumnus cirratus Temminck, 1825

Formicivora rufa (Wied, 1831)

Troglodytes aedon Vieillot, 1809

Camptostoma obsoletum (Temminck, 1824)

Elaenia albiceps (d'Orbigny \& Lafresnaye, 1837)

Elaenia chiriquensis Lawrence, 1865

Elaenia cristata Pelzeln, 1868

Elaenia flavogaster (Thunberg, 1822)

Elaenia obscura (d'Orbigny \& Lafresnaye, 1837)

Myiarchus tyrannulus (Statius Muller, 1776)

Myiodynastes maculates (Statius Muller, 1776)

Parula pitiayumi (Vieillot, 1817)

Pitangus sulphuratus (Linnaeus, 1766)

Satrapa icterophrys (Vieillot, 1818)

Todirostrum cinereum (Linnaeus, 1766)

Tolmomyias flaviventris (Wied, 1831)

Tolmomyias sulphurescens (Spix, 1825)

Tyrannus melancholicus Vieillot, 1819

\begin{tabular}{ll} 
VIREONIDAE & Hylophilus toracicus Temminck, 1822 \\
& Vireo chivi (Linnaeus, 1766) \\
\hline
\end{tabular}

Total 42

$42 \quad 331$

\begin{tabular}{|c|c|c|c|c|c|}
\hline 1 & 0 & 100 & - & - & - \\
\hline 1 & 100 & 100 & 1 & 100 & - \\
\hline 1 & 100 & 0 & - & - & - \\
\hline 2 & 50 & 100 & - & - & - \\
\hline 2 & 100 & 0 & 1 & - & 100 \\
\hline 11 & 100 & 64 & 9 & 33 & 67 \\
\hline 5 & 20 & 100 & 2 & - & 100 \\
\hline 14 & 7 & 100 & 6 & 17 & 83 \\
\hline 2 & 100 & 0 & 1 & - & 100 \\
\hline 1 & 100 & 100 & - & - & - \\
\hline- & - & - & 2 & 50 & 50 \\
\hline 6 & 67 & 50 & - & - & - \\
\hline 19 & 11 & 95 & 6 & 33 & 67 \\
\hline 3 & 33 & 100 & 1 & & 100 \\
\hline- & - & - & 2 & 50 & 50 \\
\hline 37 & 84 & 54 & 33 & 58 & 27 \\
\hline 35 & 43 & 80 & 37 & 35 & 65 \\
\hline- & - & - & 2 & - & 100 \\
\hline 19 & 5 & 95 & - & - & - \\
\hline 1 & 0 & 100 & - & - & - \\
\hline 77 & 25 & 88 & 6 & - & 100 \\
\hline 1 & 0 & 100 & - & - & - \\
\hline 6 & 100 & 17 & - & - & - \\
\hline 7 & 100 & 0 & 6 & 100 & - \\
\hline 6 & 100 & 0 & - & - & - \\
\hline 7 & 100 & 0 & 14 & 100 & - \\
\hline 1 & 0 & 100 & - & - & - \\
\hline 14 & 7 & 93 & - & - & - \\
\hline 2 & 100 & 100 & - & - & - \\
\hline 30 & 27 & 90 & 8 & 63 & 38 \\
\hline 1 & 0 & 100 & - & - & - \\
\hline 5 & 100 & 0 & 6 & 100 & - \\
\hline 1 & 100 & 0 & - & - & - \\
\hline- & - & - & 3 & 100 & - \\
\hline 1 & 0 & 100 & 3 & - & 100 \\
\hline 1 & 100 & 0 & 1 & 100 & - \\
\hline 3 & 100 & 0 & 6 & 100 & - \\
\hline 3 & 100 & 0 & - & - & - \\
\hline- & - & - & 1 & - & 100 \\
\hline 4 & 75 & 50 & 4 & 100 & - \\
\hline 1 & 100 & 0 & - & - & - \\
\hline- & - & - & 1 & 100 & - \\
\hline
\end{tabular}

$331 \quad-\quad-\quad 162$

$162-$

Total number of events of ground foraging (glean on the ground does not appear in the table): Mimus gilvus $=2$ and Zonotrichia capensis = 10 . 


\begin{tabular}{|c|c|c|c|c|c|c|c|c|c|c|c|c|c|c|c|}
\hline \multicolumn{9}{|c|}{ Behavior } & \multirow{2}{*}{\multicolumn{4}{|c|}{$\begin{array}{l}\text { Height } \\
\text { (m) }\end{array}$}} & \multirow{2}{*}{\multicolumn{3}{|c|}{$\begin{array}{c}\text { Position } \\
\text { (\% of plant height) }\end{array}$}} \\
\hline Glean & & & & allie & & & & Hawk & & & & & & & \\
\hline$\frac{\widetilde{\varpi ్}}{\widetilde{J}}$ & 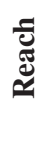 & 溤 & 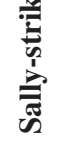 & 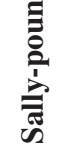 & 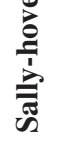 & త్త్ & $\stackrel{8}{\Xi}$ & 望 & $\theta$ & 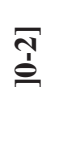 & 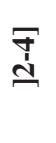 & $\stackrel{18}{ \pm}$ & $\overline{8}$ & î̀ & $\bar{z}$ \\
\hline
\end{tabular}


Gomes, V.S.M. et al.
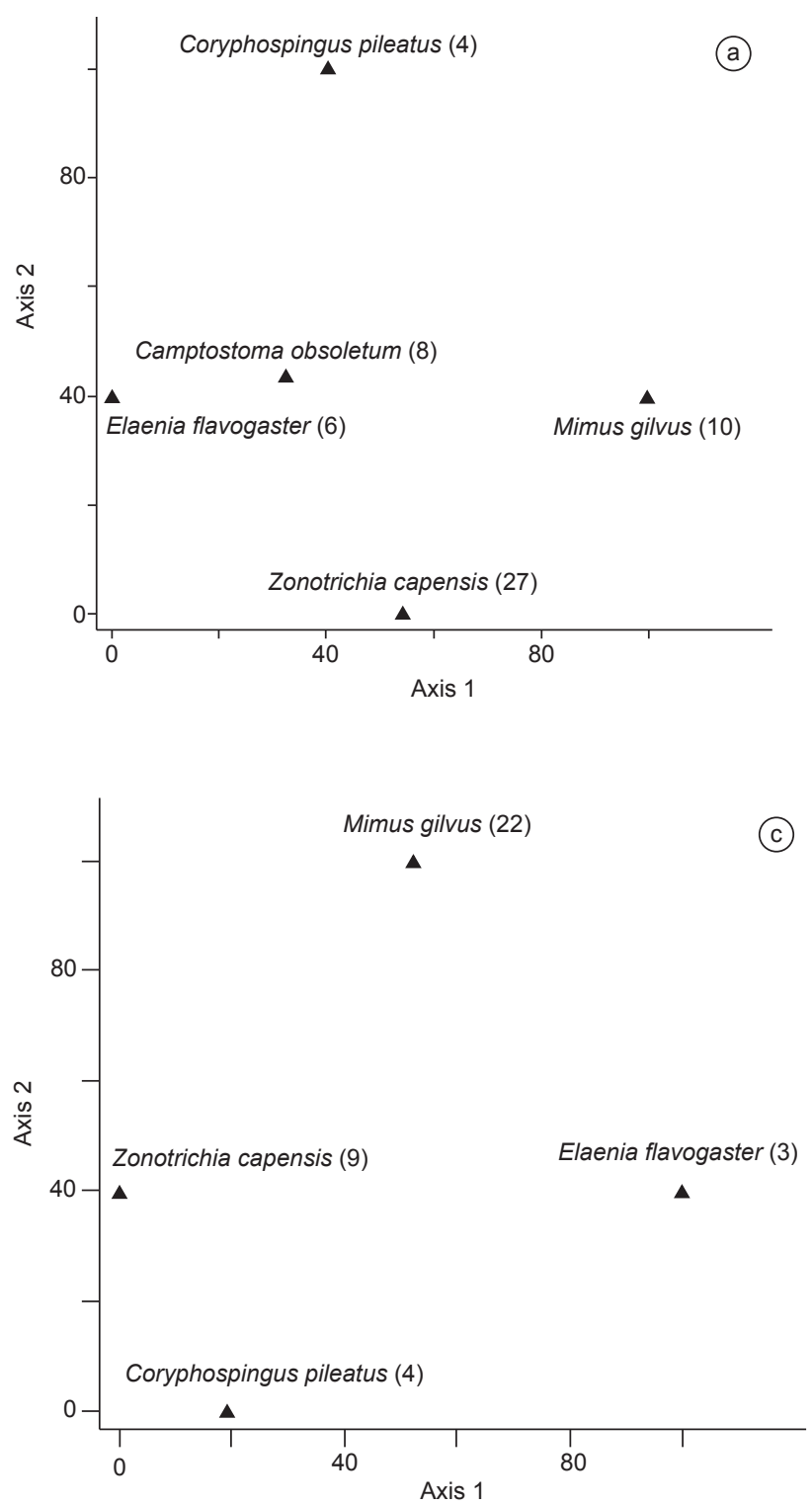
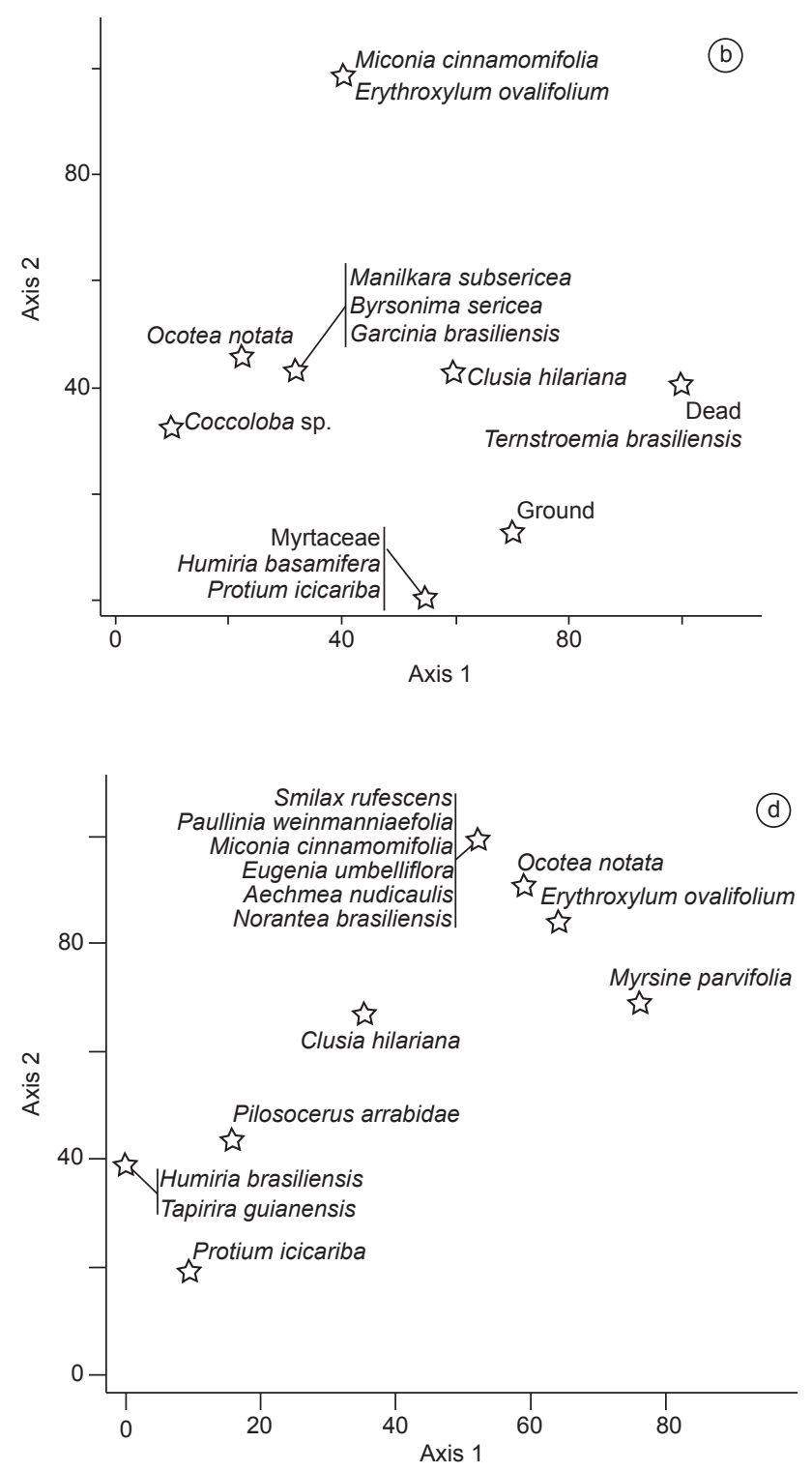

Figure 2. Bray-Curtis Ordination (BCO) of the studied species considering plant species used for foraging for arthropods (a-birds scores, b-plants scores), and plant species used for foraging for fruits (c-birds scores, d-plants scores) at Restinga de Jurubatiba, Rio de Janeiro State, Brazil. (Scores for the birds are triangles and for the variables are stars; in parenthesis, the number of independent samples for each species).

Figura 2. Ordenação de Bray-Curtis (BCO) das espécies estudadas considerando espécies utilizadas para forrageamento por artrópodos (a-posições das aves, b-posições das plantas) e espécies utilizadas para forrageamento por frutos (c-posições das aves, d-posições das plantas) na Restinga de Jurubatiba, estado do Rio de Janeiro, Brasil. (Posições das aves são triângulos e das variáveis são estrelas; em parênteses, o número de amostras independentes para cada espécie).

the tropical forest sensu strictu, and only those species with foraging strategies capable to allow survivorship in other habitats expanded their distributions to marginal habitats, such as restinga. This idea is corroborated by the fact that most species have their origin attributed to other habitats or biomes (Reis \& Gonzaga 2000).

Most birds species studied were frugivorous at some level, including the non-breeding birds at the study site Turdus amaurochalinus Cabanis, Platycichla flavipes (Vieillot), Tangara peruviana (Desmarest), Cyanerpes cyaneus (Linnaeus) and Elaenia albiceps (d'Orbigny \& Lafresnaye), E. chiriquensis Lawrence, E. cristata Pelzeln, E. obscura (d'Orbigny \& Lafresnaye). Plants, therefore, are extremely important to that avifauna not only as foraging substrates, but also as direct sources of food. Frugivores have also been found to be numerically important in lowland wet forests in Costa Rica (30\% of the total avifauna), especially among migrants (2/3 of the species) (Blake \& Loiselle 1992). Furthermore, the probability of finding fruits and not arthropods in the diet of migrant omnivorous birds may be greater during migration than in breeding sites, as many species tend to increase their consumption of fruits before and during migration (Wheelwright 1986, Martin et al. 1931 and Berthold 1976 apud Levey \& Karasov 1989, Blake \& Loiselle 1992).

The foraging maneuver mostly used by birds in restinga was glean, which was also found by Beissinger \& Osborne (1982) and Volpato \& Anjos (2001) in urban habitats and is presumably the maneuver that requires lower energy-expenditure (Remsen 1985). We found that ordination based on foraging maneuvers grouped 
Birds foraging in restinga

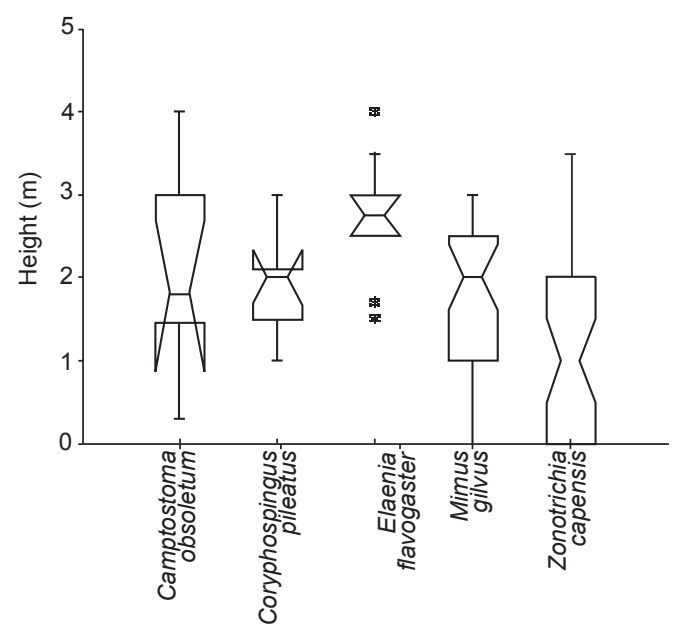

Figure 3. Box plots of foraging heights of the studied species at Restinga de Jurubatiba, Rio de Janeiro State, Brazil (internal horizontal line = median; whiskers = minimum and maximum values; box horizontal limits: inferior $=$ $25 \%$ quartile, superior $=75 \%$ quartile; asterisks $=$ outliers. Boxes are notched at the median and return to full width at the lower and upper 95\% confidence limits of the median). (for number of samples, see Table 1).

Figura 3. Distribuição das alturas de forrageio das espécies estudadas na Restinga de Jurubatiba, Estado do Rio de Janeiro, Brasil. (linha horizontal interna = mediana; traços horizontais = valores mínimos e máximos; limites horizontais das caixas: inferior $=$ quartil de $25 \%$, superior $=$ quartil de $75 \%$; asteriscos $=$ outliers. As caixas são mais estreitas na mediana e retornam para a largura total nos limites de $95 \%$ de confiança inferior e superior da mediana). (para número de amostras, veja Tabela 1).

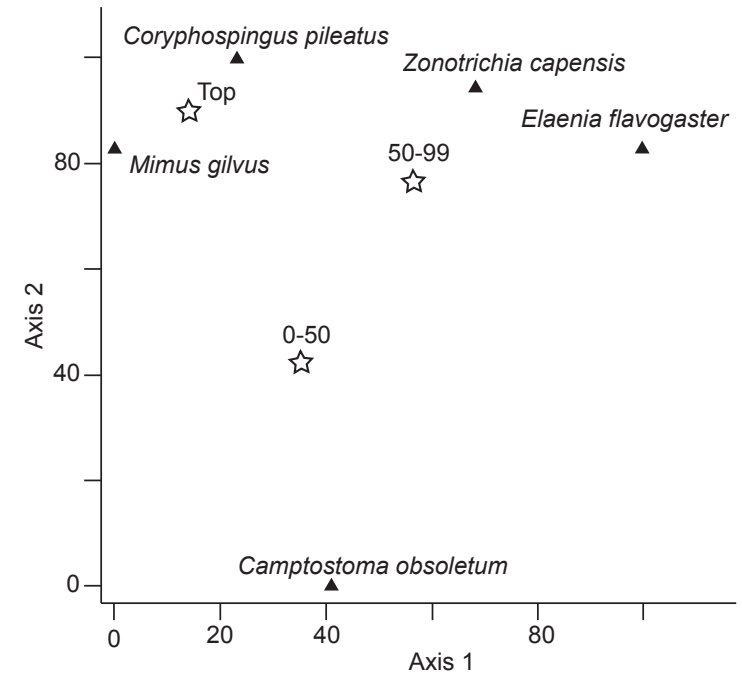

Figure 4. Bray-Curtis Ordination (BCO) of the studied species considering foraging positions (percent of plant height), at Restinga de Jurubatiba, Rio de Janeiro State, Brazil. (Scores for the birds are triangles and for the variables are stars; for number of samples, see Table 1).

Figura 4. Ordenação de Bray-Curtis (BCO) das espécies estudadas considerando posição de forrageio (percentagem da altura da planta), na Restinga de Jurubatiba, Estado do Rio de Janeiro, Brasil. (Posições das aves são triângulos e das variáveis são estrelas; para número de amostras, veja Tabela 1).

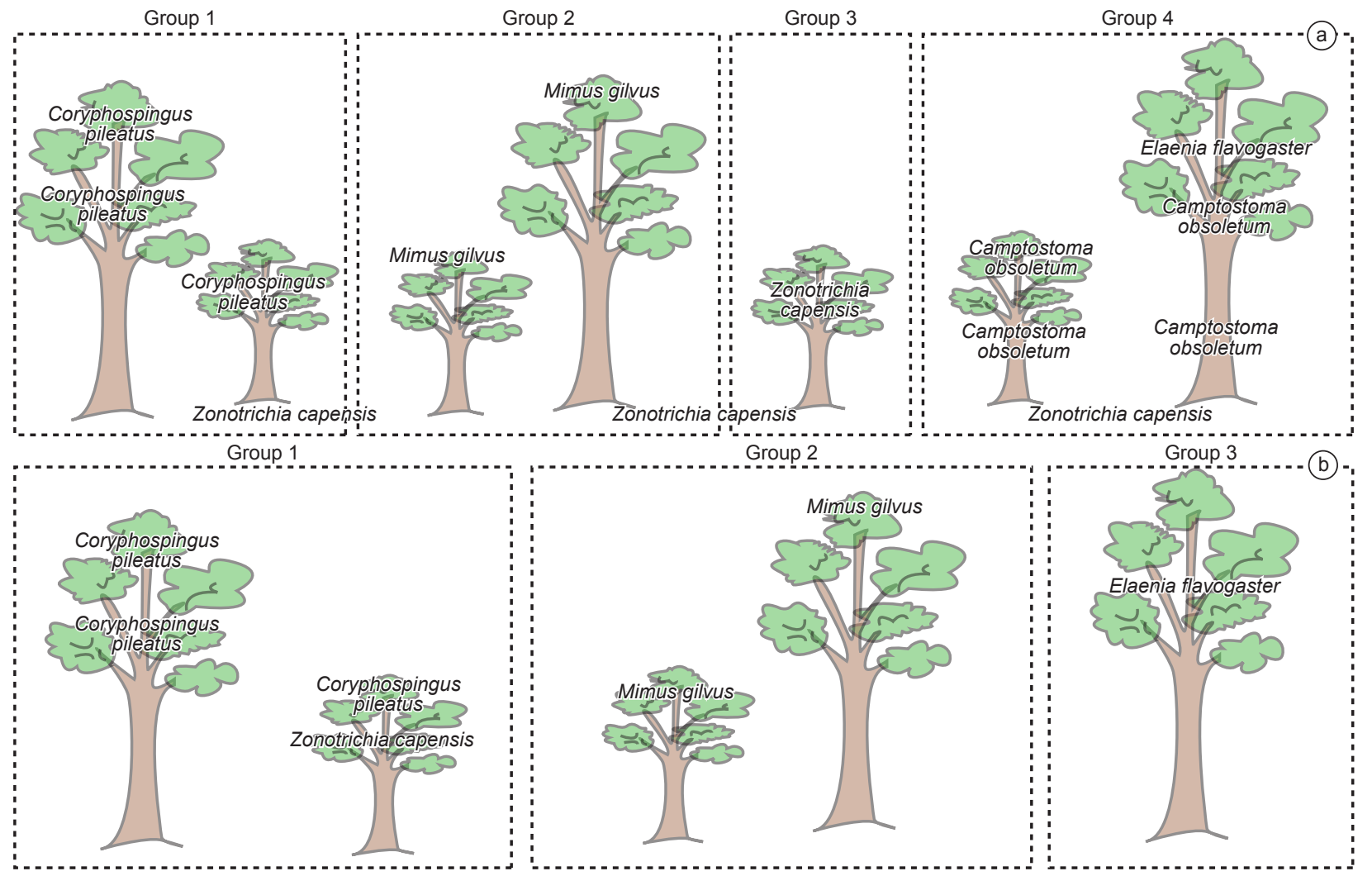

Figure 5. Spatial display of the studied birds when foraging for a) arthropods and for b) fruits, at Restinga de Jurubatiba, Rio de Janeiro State, Brazil. (Plant species most used are based on Figure 2, foraging heights on Figure 3 and positions on Figure 4; "Groups" represent groups of plant species).

Figura 5. Disposição espacial das espécies de aves estudadas durante o forrageio por a) artrópodos e por b) frutos, na Restinga de Jurubatiba, Estado do Rio de Janeiro, Brasil. (espécies de plantas mais utilizadas estão baseadas na Figura 2, alturas de forrageio na Figura 3 e posições na Figura 4; "Groups" representam grupos de espécies de plantas). 
Table 2. Plant species availability (IVI, see text) and preference (Jacobs' index, see text) by the most common terrestrial birds observed feeding for arthropods at Restinga de Jurubatiba, Rio de Janeiro State, southeastern Brazil (in bold, positive Jacob's index values. -1.0 indicates that birds were never observed foraging on this plant. - means no data).

Tabela 2. Disponibilidade de espécies de plantas (IVI, veja texto) e preferência (índice de Jacob, veja texto) pelas aves terrestres mais comumente observadas forrageando por artrópodos na Restinga de Jurubatiba, Estado do Rio de Janeiro, sudeste do Brasil (em negrito, valores positivos do índice de Jacob. -1.0 indica que as aves nunca foram observadas forrageando nessa planta. - significa ausência de dados).

\begin{tabular}{|c|c|c|c|c|c|c|}
\hline Plant Species & IVI & $\begin{array}{c}\text { Camptostoma } \\
\text { obsoletum }\end{array}$ & $\begin{array}{c}\text { Coryphospingus } \\
\text { pileatus }\end{array}$ & $\begin{array}{c}\text { Elaenia } \\
\text { flavogaster }\end{array}$ & $\begin{array}{l}\text { Mimus } \\
\text { gilvus }\end{array}$ & $\begin{array}{l}\text { Zonotrichia } \\
\text { capensis }\end{array}$ \\
\hline Andira sp. & 0.02 & -1.0 & -1.0 & -1.0 & -1.0 & -1.0 \\
\hline Byrsonima sericea DC. & 0.10 & 0.1 & -1.0 & -1.0 & -1.0 & -1.0 \\
\hline Clusia hilariana Schltdl. & 0.48 & -0.5 & -0.5 & -0.6 & 0.5 & -0.1 \\
\hline Dead & 0.14 & -1.0 & -1.0 & -1.0 & -0.1 & -1.0 \\
\hline Erythroxylum ovalifolium Peyr. & 0.13 & -1.0 & 0.4 & -1.0 & -1.0 & -1.0 \\
\hline $\begin{array}{l}\text { Erythroxylum subsessile } \\
\text { (Mart.) O. E. Schulz }\end{array}$ & 0.11 & -1.0 & -1.0 & -1.0 & -1.0 & -1.0 \\
\hline Garcinia brasiliensis Mart. & 0.00 & 1.0 & - & - & - & - \\
\hline Guapira opposita (Vell.) Reitz & 0.03 & -1.0 & -1.0 & -1.0 & -1.0 & -1.0 \\
\hline $\begin{array}{l}\text { Humiria balsamifera (Aubl.) } \\
\text { A. St.-Hil. }\end{array}$ & 0.07 & -1.0 & -1.0 & -1.0 & -1.0 & -0.1 \\
\hline $\begin{array}{l}\text { Manilkara subsericea } \\
\text { (Mart.) Dubard }\end{array}$ & 0.08 & 0.3 & -1.0 & -1.0 & -1.0 & -1.0 \\
\hline Maytenus obtusifolia Mart. & 0.01 & -1.0 & -1.0 & -1.0 & -1.0 & -1.0 \\
\hline $\begin{array}{l}\text { Miconia cinnamomifolia } \\
\text { (DC.) Naudin }\end{array}$ & 0.12 & -1.0 & 0.4 & -1.0 & -1.0 & -1.0 \\
\hline Myrsine parvifolia A. DC & 0.18 & -1.0 & -1.0 & -1.0 & -1.0 & -1.0 \\
\hline Myrtaceae & 0.41 & -1.0 & -1.0 & -1.0 & -1.0 & -0.7 \\
\hline Ocotea notata (Nees) Mez & 0.16 & 0.5 & 0.3 & 0.8 & -1.0 & 0.4 \\
\hline Ouratea cuspidata (A. St.-Hil.) Engl. & 0.08 & -1.0 & -1.0 & -1.0 & -1.0 & -1.0 \\
\hline Paullinia weinmanniaefolia Mart. & 0.02 & -1.0 & -1.0 & -1.0 & -1.0 & -1.0 \\
\hline Protium icicariba (DC.) Marchand & 0.61 & -1.0 & -1.0 & -1.0 & -1.0 & -0.9 \\
\hline Ternstroemia brasiliensis Cambess. & 0.05 & -1.0 & -1.0 & -1.0 & 0.4 & -1.0 \\
\hline Tibouchina sp. & 0.05 & -1.0 & -1.0 & -1.0 & -1.0 & -1.0 \\
\hline Tocoyena bullata Mart. & 0.06 & -1.0 & -1.0 & -1.0 & -1.0 & -1.0 \\
\hline Xylopia ochrantha Mart. & 0.09 & -1.0 & -1.0 & -1.0 & -1.0 & -1.0 \\
\hline Sample size & 400 & 8 & 4 & 6 & 10 & 27 \\
\hline
\end{tabular}

species in accordance to the literature as Tyrannidae (E. flavogaster and $C$. obsoletum) generally use their wings (hawk and sallies) and Emberizinae (C. pileatus and Z. capensis) glean from perches (Moermond \& Denslow 1985, Moermond et al. 1986). Mimus gilvus, however, also used winged maneuvers to forage, as well as foraged from the ground; this species was positioned with Z. capensis in the ordination. Tyrants were investigated in greater detail in other works: Camptostoma spp. used only gleaning manuevers (Fitzpatrick 1980), although C. obsoletum used glean and sally-strike in the same proportions (Gabriel \& Pizo 2005), and Elaenia spp used only sallies (Fitzpatrick 1980, Cintra 1997, Gabriel \& Pizo 2005). Those behaviors seem to be conservative for the species, independently of habitat, being forest edges or shrubby vegetations, as in restinga. Likely, species that frequently hawk are limited to open habitats. All of the tyrants studied here (see Table 1) are typical of open habitats (Sick 1997) and they were recorded more frequently in shrubby restinga than in restinga forest at the study site (Gomes 2006). Those species, when recorded in the forest, were perched in or foraging from the forest canopy. Cintra (1997) studied the foraging behavior of tyrants in forest and field in the Amazon, and from the species that occurred in both habitats, their behaviors were conservative. In fact, the tallest trees ( 2 to $4 \mathrm{~m}$; mainly Ocotea notata) seemed to be important especially for E. flavogaster and other tyrants. This species, in particular, was usually observed in pairs in the canopy, from where one of the individuals left and returned to meet the other after foraging (pers. obs.). The preference of tyrants for tall trees had already been shown by Cintra (1997) and it is related to their aerial maneuvering (Fitzpatrick 1980).

In contrast, Z. capensis and M. gilvus were the only species capable of frequent ground-foraging during the study, although the latter preferred greater heights. Mimus saturninus (Lichtenstein) was observed feeding on unpaved and paved grounds in a university campus of southern Brazil (Volpato \& Anjos 2001); Mimus polyglottos (Linnaeus) also frequently foraged on the ground in North America (Breitwisch et al. 1987). Zonotrichia capensis is also known to forage on the ground (Sick 1997). Half of the species and individuals of resident birds of a desert shrubland in North America foraged on the ground (Parker 1986), which was attributed to a dominance of foodgeneralist species in a highly unpredictable habitat. In the restinga studied in the present work, precipitation is not totally unpredictable, but may be scarce in the middle of the year. Furthermore, although arthropods and fruits fluctuate in abundance, there is no season of scarcity of those resources (Monteiro \& Macedo 2000, Gomes 2006). Foraging on the ground, birds likely encounter different arthropod prey than that found on plant surfaces (data not shown). Besides being generalists in feeding maneuvers, those species have a generalist diet 
(Sick 1997, Gomes 2006). Generalist foraging strategies may have resulted in greater population abundances; they were among the five most abundant resident birds both in mist-netting and observations during two years of sampling (Alves et al. 2004).

In general, bird species did not overlap much while foraging, although some plants used by $C$. obsoletum to forage for arthropods coincided with those used by E. flavogaster. However, the latter species used mostly sallies and the former mostly glean, which likely resulted in each species foraging in different microhabitats of the same plant. In fact, three of the items observed to be consumed by $C$. obsoletum were Homoptera that formed a white layer on the lower surface of the leaves of $C$. hilariana and Manilkara subsericea (Mart.) Dubard; in contrast, E. flavogaster was never seen consuming Homoptera.

Coryphospingus pileatus and Z. capensis also overlapped in shorter vegetation while feeding on fruits. Indeed, both species were occasionally observed foraging for fruits in mixed flocks, while on other occasions, Z. capensis captured ants on the ground. This last species is known to forage in mixed flocks (Machado 1999). The fact that fruits of a given species are ephemeral and patchy may explain flocking in birds, which facilitates encountering such resources Saracco et al. (2004). Besides that, mixed flocks also take advantage of a greater vigilance against predators (Powell 1985), which in an open habitat as the shrubby restinga may be critical. This seems to be the case for the cerrado (Tubelis et al. 2006, Alves \& Cavalcanti 1996), a Brazilian biome that also has open vegetation.

Birds' preference for $O$. notata may, in part, be related to the architecture of this tree, which provided a better visibility of the foraging birds to the observer than other species did (pers. obs.). On the other hand, $M$. gilvus probably preferred to forage on $C$. hilariana for arthropods probably because it is a tall tree, from where this bird may defend its territory and also obtain some fruit when possible (pers. obs.). Such apparent plant preferences for $O$. notata and $C$. hilariana, may simply reflect that they were among the six species with the greatest importance values in a phytosociological study of the same plant formation (Araujo et al. 2004).

Although restinga is a marginal habitat in the Atlantic forest, frugivorous and insectivorous birds foraged similarly to other Neotropical habitats. Concerning birds and their foraging ecologies, it seems that Restinga de Jurubatiba preserves its ecological patterns, as indicated formerly by Rocha et al. (2003). The present work is further evidence of the importance of birds for conservation of this restinga vegetation structure and plant composition. Our main contribution to restoration measures in restinga were having pointed out that Clusia and Ocotea are important plants to attract bird species, which in turn, could disperse their seeds and other plant species' (Gomes et al. 2008), helping the successional process. Future studies should evaluate in more detail bird species behavior and habitat requirements, trying to unmask differences in fitness among forest and marginal habitats as restingas.

\section{Acknowledgements}

To the members of Laboratório de Ecologia de Aves, Departamento de Ecologia, Universidade do Estado do Rio de Janeiro (UERJ) (especially Alline Storni, Adriano Lagos, Vanessa C. Tomaz), Charles Ozanick, Francisco Mallet-Rodrigues, Karina Amaral, Davor Vrcibradic, Carlos Humberto Oliveira, Mariana Janiszewski, Ricardo Freitas, Barbara L. Ignacio and Renata P. N. Lima for helping in the field work. To Dorothy S. D. Araujo and Alexandre Quinet (Ocotea) for the identification of the plants. To Luiz Fábio Silveira and Érica Hasui for helping with Elaenia spp. identification at Museu de Zoologia da Universidade de São Paulo (MUZUSP) and Marcos
Raposo for helping at Museu Nacional do Rio de Janeiro (MNRJ). To Coordenação de Aperfeiçoamento de Pessoal de Nível Superior (CAPES) and Fundação de Apoio à Pesquisa do Estado do Rio de Janeiro (FAPERJ) for scholarships to V. S. M. Gomes. To Conselho Nacional de Desenvolvimento Científico e Tecnológico (CNPq), for the research grant awarded to M. A. S. Alves (process number 302718/03-6). To Idea Wild for the mist nets and to Instituto Biomas and UERJ for the vehicles used in the field. To Núcleo de Pesquisas de Macaé (NUPEM) for the logistic facilities. This work is a sub-project of Grupo de Vertebrados/PELD - site 5/CNPq. Birds were captured under the license number P029/03 (CEMAVE/IBAMA) and collection of specimens under the licenses number 106/2003 and 116/2004 (IBAMA/DIREC - PARNA Restinga de Jurubatiba), 056/2002 and 093/2004 (IBAMA/Fauna) and 163/2005 (IBAMA/Flora).

\section{References}

AIROLA, D.A. \& BARRETT, R.H. 1985. Foraging and habitat relationships of insect-gleaning birds in a Sierra Nevada mixed-conifer forest. Condor 87(2):205-216

ALVES, M.A.S. \& CAVALCANTI, R.B. 1996. Sentinel behavior, seasonality and the structure of bird flocks in a Brazilian savanna. Ornitologia Neotropical 7(1):43-51.

ALVES, M.A.S., STORNI, A., ALMEIDA, E.M., GOMES, V.S.M., OLIVEIRA, C.H.P., MARQUES, R.V. \& VECCHI, M.B. 2004. A comunidade de aves na Restinga de Jurubatiba. In Pesquisas ecológicas de longa duração na Restinga de Jurubatiba: Ecologia, História Natural e Conservação (Rocha, C.F.D., Esteves, F.A. \& Scarano, F. R., eds.) RiMa, São Carlos, p.199-214.

ARAUJO, D.S.D., SCARANO, F.R., SÁ, C.F.C., KURTZ, B.C., ZALUAR, H.L.T., MONTEZUMA, R.C.M. \& OLIVEIRA, R.C. 1998. Comunidades Vegetais do Parque Nacional da Restinga de Jurubatiba. In Ecologia das Lagoas Costeiras do Parque Nacional da Restinga de Jurubatiba e do Município de Macaé (F.A. Esteves, ed.). UFRJ, Rio de Janeiro, p. 39-62.

ARAUJO, D.S.D., PEREIRA, M.C.A. \& PIMENTEL, M.C.P. 2004. Flora e estrutura de comunidades na Restinga de Jurubatiba - Síntese dos conhecimentos com enfoque especial para a Formação Aberta de Clusia. In Pesquisas ecológicas de longa duração na Restinga de Jurubatiba: Ecologia, História Natural e Conservação (Rocha, C. F. D., Esteves, F. A., \& Scarano, F. R., eds.). RiMa, São Carlos, p. 59-76.

ARGEL-DE-OLIVEIRA, M.M. 1999. Frugivoria por aves em um fragmento de Floresta de Restinga no Estado do Espírito Santo, Brasil. Phd Thesis, Universidade Estadual de Campinas, Campinas.

BEALS, E. 1984. Bray-Curtis Ordination: An Effective Strategy for Analysis of Multivariate Ecological Data. Adv. Ecol. Res. 14:1-55.

BELL, G.W., HEJL, S.J. \& VERNER, J. 1990. Proportional use of substrates by foraging birds: model considerations on first sightings and subsequent observations. Studies in Avian Biology 13:161-165.

BEISSINGER, S.R. \& OSBORNE, D.R. 1982. Effects of urbanization on avian community organization. Condor 84(1):75-83.

BLAKE, J.G. \& LOISELLE, B.A. 1992. Fruits in the diets of neotropical migrant birds in Costa Rica. Biotropica 24(2):200-210.

BLEHER, B. \& BOHNING-GAESE, K. 2001. Consequences of frugivore diversity for seed dispersal, seedling establishment and the spatial pattern of seedlings and trees. Oecologia 129(3):385-394.

BREITWISCH R., DIAZ, M. \& LEE, R. 1987 Foraging efficiencies and techniques of juvenile and adult northern mockingbirds (Mimus polyglottos). Behaviour 101(1-3):225-235.

BROWER, J.E. \& ZAR, J.H. 1984. Field \& Laboratory methods for general ecology. Dubuque.

CANTERBURY, G.E., MARTIN, T.E., PETIT, D.R., PETIT, L.J. \& BRADFORD, D.F. 2000. Bird communities and habitat as ecological indicators of forest condition in regional monitoring. Conserv. Biol. 14(2):544-558 
CASTIGLIONI, G.D.A. 1998. Biologia reprodutiva e organização social de Ramphocelus bresilius (Passeriformes: Emberizidae) na Restinga de Barra de Marica, Estado do Rio de Janeiro. Master thesis, Universidade Estadual de Campinas, Campinas.

CBRO [online] 2007. Comitê Brasileiro de Registros Ornitológicos. http:// www.cbro.org.br/CBRO/index.htm (último acesso em 26/12/2005).

CERQUEIRA, R. 2000. Biogeografia das restingas. In Ecologia de restingas e lagoas costeiras (Esteves, F.A. \& Lacerda, L.D. eds.). NUPEMIUFRJ, Rio de Janeiro, p.65-75.

CINTRA, R. 1997. Spatial distribution and foraging tactics of tyrant flycatchers in two habitats in the Brazilian Amazon. Stud. Neotrop. Fauna Environ. 32(1):17-27.

DUNNING, J.S. 1989. South American Birds. A photographic aid to identification. Harrowood Books, Newton Square.

FITZPATRICK, J. W. 1980. Foraging behavior of neotropical tyrant flycatchers. Condor 82(1):43-57.

GABBE, A.P., ROBINSON, S.K. \& BRAWN, J.D. 2002. Tree-species preferences of foraging insectivorous birds: implications for floodplain forest restoration. Conserv. Biol. 16(2):462-470.

GABRIEL, V.A. \& PIZO, M.A. 2005. Foraging behavior of tyrant flycatchers (Aves, Tyrannidae) in Brazil. Revta bras. Zool. 22(4):1072-1077.

GOMES, V.S.M. 2006. Variação espacial e dieta de aves terrestres na Restinga de Jurubatiba. PhD Thesis, Universidade Federal do Rio de Janeiro, Rio de Janeiro.

GOMES, V.S.M., CORREIA, M.C.R., LIMA, H.A. \& ALVES, M.A. 2008. Potential role of frugivorous birds (Passeriformes) on seed dispersal of six plant species of a restinga habitat, southeastern Brazil. Rev. biol. trop. 56(1):205-216.

GONZAGA, L.P., CASTIGLIONI, G.D.A. \& REIS, H.B.R. 2000. Avifauna das restingas do Sudeste: estado do conhecimento e potencial para futuros estudos. In Ecologia de restingas e lagoas costeiras (Esteves, F.A. \& Lacerda, L.D. eds.). NUPEMIUFRJ, Rio de Janeiro, p.151-163.

GORCHOV, D.L., CORNEJO, F., ASCORRA, C. \& JARAMILLO, M. 1993. The role of seed dispersal in the natural regeneration of rain Forest after strip-cutting in the Peruvian Amazon. Vegetatio 107/108:339-349.

HASUI, E., GOMES, V.S.M. \& SILVA, W.R. 2007. Effects of vegetation traits on habitat preferences of frugivorous birds in Atlantic Rain Forest. Biotropica 39(4):502-509.

HEJL, S.J., VERNER, J. \& BELL, G.W. 1990. Sequential versus initial observations in studies of avian foraging. Studies in Avian Biology 13:166-173.

HENRIQUES, R.P.B., ARAUJO, D.S.D. \& HAY, J.D. 1986. Descrição e classificação dos tipos de vegetação da restinga de Carapebus, Rio de Janeiro. Rev. bras. Bot. 9(2):173-189.

HOLMES, R.T. \& RECHER, H.F. 1986. Search tactics of insectivorous birds foraging in an Australian eucalypt forest. Auk 103(3):515-530.

HOLMES, R.T., BONNEY Jr., R.E. \& PACALA, S.W. 1979. Guild structure of the Hubbard Brook bird community: a multivariate approach. Ecology 60(3):512-520.

HOWE, H.F. \& MIRITI, M.N. 2000. No question: seed dispersal matters. Trends Ecol. Evol. 15(11):434-436.

JACOBS, J. 1974. Quantitative measurement of food selection. Oecologia 14(4):413-417.

LACERDA, L.D., ARAUJO, D.S.D. \& MACIEL, N.C. 1993. Dry coastal ecosystems of the tropical Brazilian coast. In Dry Coastal Ecosystems: Africa, America and Oceania (van der Maarel, E., ed.). Elsevier, Amsterdam, p. 477-493.

LEVEY, D. J. \& KARASOV, W. H. 1989. Digestive responses of temperate birds switched to fruit or insect diets. Auk 106(4):675-686.

MACARTHUR, R.H. 1958. Population ecology of some warblers of northeastern coniferous forest. Ecology 39(4):599-619.

MACHADO, C.G. 1999. A composição dos bandos mistos de aves na Mata Atlântica da Serra de Paranapiacaba, no Sudeste Brasileiro. Rev. Bras. Biol. 59(1):75-85.
MCCLANAHAN, T.R. \& WOLFE, R.W. 1993. Accelerating forest succession in a fragmented landscape: the role of birds and perches. Conserv. Biol. $7(2): 279-288$.

MCCUNE, B. \& GRACE, J. B. 2002. Analysis of Ecological Communities. MjM Software Design, Gleneden Beach.

MCCUNE, B. \& MEFFORD, M.J. 1999. Multivariate Analysis of Ecological Data. PC-Ord. Version 4.10. MjM Software, Gleneden Beach.

MELI, P. 2003. Restauración ecológica de bosques tropicales. Veinte años de investigación académica. Interciência 28(10):581-589.

MOERMOND, T.C. \& DENSLOW, J.S. 1985. Neotropical avian frugivores: patterns of behaviour, morphology, and nutrition with consequences for food selection. Ornithological Monographs 36:865-897.

MOERMOND, T.C., DENSLOW, J.S., LEVEY, D.J. \& SANTANA C.E. 1986. The influence of morphology on fruit choice in neotropical birds. In Frugivores and seed dispersal (Estrada, A. \& Fleming, T.H., eds.). Dr W Junk Publishers, Dordrecht, p. 137-146.

MONTEIRO, R.F. \& MACEDO, M.V. 2000. Flutuação populacional de insetos fitófagos em restinga. In Ecologia de restingas e lagoas costeiras (Esteves, F.A. \& Lacerda, L.D., eds.) NUPEM $\backslash U F R J$, Rio de Janeiro, p.77-88.

NOVAES, F.C. 1950. Sobre as aves de Sernambetiba, Distrito Federal, Brasil. Rev. Bras. Biol. = Braz. J. Biol. 10(2):199-208.

PARKER, K.C. 1986. Partitioning of foraging space and nest sites in a desert shrubland bird community. Am. Midl. Nat. 115(2): 254-267.

PIMENTEL, M. 2002. Variação espacial na estrutura de comunidades vegetais da Formação Aberta de Clusia no Parque Nacional da Restinga de Jurubatiba, RJ. PhD Thesis, Universidade Federal do Rio de Janeiro, Rio de Janeiro.

PIZO, M.A. 1997. Seed dispersal and predation in two population of Cabralea canjerana (Meliaceae) in the Atlantic Forest of southeastern Brazil. J. Trop. Ecol. 13(4):559-578.

POWELL, G.V.N. 1985. Sociobioloy and adaptive significance of heterospecific foraging in the Neotropics. Ornithological Monographs 36:713-732

REIS, H.B.R. \& GONZAGA, L.P. 2000. Análise da distribuição geográfica das aves das restingas do Estado do Rio de Janeiro. In Ecologia de restingas e lagoas costeiras (Esteves, F.A. \& Lacerda, L.D., eds.) NUPEM\UFRJ, Rio de Janeiro, p. 165-178.

REMSEN Jr., J.V. 1985. Community organization and ecology of birds of high elevation humid forest of the Bolivian Andes. Ornithological Monographs 36:733-756.

REMSEN, J.V. \& ROBINSON, S.K. 1990. A classification scheme for foraging behavior of birds in terrestrial habitats. Studies in Avian Biology $13: 144-160$.

RIZZINI, C.T. 1979. Tratado de fitogeografia do Brasil. Aspectos sociológicos e florísticos. vol. 2. Universidade de São Paulo, São Paulo.

ROBINSON, S.K. \& HOLMES, R.T. 1982. Foraging behavior of forest birds: the relationships among search tactics, diet, and habitat structure. Ecology 63(6):1918-1931.

ROBINSON, S.K. \& HOLMES, R.T. 1984. Effects of plant species and foliage structure on the foraging behavior of forest birds. Auk 101(4):672-684.

ROCHA, C.F.D., BERGALLO, H.G., ALVES, M.A.S. \& VANSLUYS, M. 2003. A biodiversidade nos grandes remanescentes florestais do Estado do Rio de Janeiro e nas restingas da Mata Atlântica. RiMa, São Carlos.

SARACCO, G.M., COLLAZO, J.A \& GROOM, M.J.. 2004. How do frugivores track resources? Insights from spatial analyses of bird foraging in a tropical forest. Oecologia 139(2):235-245.

SCARANO, F.R. 2002. Structure, function and floristic relationships of plant communities in stressful habitats marginal to the Brazilian Atlantic Forest. Ann. Botany 90(4):517-524.

SCHERER, A., MARASCHIN-SILVA, F. \& BAPTISTA, L.R.M. 2007. Padrões de interações mutualísticas entre espécies arbóreas e aves frugívoras em uma comunidade de Restinga no Parque Estadual de Itapuã, RS, Brasil. Acta bot. bras. 21(1):203-212. 
SCHUPP, E.W. 1993. Quantity, quality and the effectiveness of seed dispersal by animals. Vegetatio 107/108:15-29.

SEKERCIOGLU, C.H. 2002. Effects of forestry practices on vegetation structure and bird community of Kibale National Park, Uganda. Biol. Conserv. 107(2):229-240.

SICK, H. 1997. Ornitologia brasileira. Nova Fronteira, Rio de Janeiro.

SORENSEN, A.E. 1984. Nutrition, energy and passage time: experiments with fruit preference in European blackbirds (Turdus merula). J. Anim. Ecol. 53(2):545-557.

STILES, E.W. 1992. Animals as seed dispersers. In The ecology of regeneration in plant communities (Fenner, M. ed.) CAB International, Wallingford, p. 87-104.

SYLVESTRE, L.S. \& ROSA, M.M.T. 2002. Manual metodológico para estudos botânicos na Mata Atlântica. Universidade Rural, Seropédica.

SYSTAT 1990. SYSTAT 5.03 for windows. SYSTAT Inc, Evanston.

TUBELIS, D.P., COWLING, A. \& DONNELLY, C. 2006. Role of mixedspecies flocks in the use of adjacent savannas by forest birds in the central Cerrado, Brazil. Austral Ecol. 31(1):38-45.

VAN BALL, S.A., BRAWN, J.D. \& ROBINSON, S.K. 2003. Birds defend trees from herbivores in a Neotropical forest canopy. Proc. Natl. Acad. Sci. USA 100(14): 8304-8307.
VENTURINI, A.C., OFRANTI, M.A.S., VAREJÃO, J.B.M. \& PAZ, P.R. 1996. Aves e mamíferos na restinga. Governo do Estado do Espírito Santo, Vitória.

VOLPATO, G.H. \& ANJOS, L. 2001. Análise das estratégias de forrageamento das aves que se alimentam no solo na Universidade Estadual de Londrina, Estado do Paraná. Ararajuba 9(2):95-99.

WARBURTON, B., KINGSFORD, S.J., LEWITT, D.W. \& SPURR, E.B. 1992. Plant-species preferences of birds in Lowland Rimu (Dacrydium cupressinum) forest - implications for selective-logging. New Zealand Journal Of Ecology 16(2):119-126.

WHEELWRIGHT, N.T. 1986. The diet of American Robins: an analysis of U.S. Biological Survey records. Auk 103(4):710-725.

WHELAN, C.J. 2001. Foliage structure influences foraging of insectivorous forest birds: an experimental study. Ecology 82(1):219-231.

WIENS, J.A. 1989. The ecology of bird communities: Foundations and patterns. Cambridge University, Cambridge.

WITMER, M.C. \& VAN SOEST, P.J. 1998. Contrasting digestive strategies of fruit-eating birds. Funct. Ecol. 12(5):728-741.

WOLDA, H. 1990. Food availability for an Insectivore and how to measure it. Studies in Avian Biology 13:38-43.

Data Received 21/11/07

Revised 29/08/08

Accepted 01/10/08 